\title{
Аудирование в обучении детей мигрантов русскому языку: предтекстовая работа
}

В статье рассматриваются приемы, способствующие формированию навыков аудирования на этапе предтекстовой работы. Опыт обучения детей мигрантов показал, что данные приемы снимают часть аудитивных трудностей и позволяют использовать аутентичные звучащие материалы уже на начальном этапе обучения русскому языку как неродному.

Исследование выполнено при финансовой поддержке РФФИ в рамках научного проекта №19-013-00213.

Ключевые слова: русский язык как неродной, речевая деятельность, аудирование, предтекстовая работа, дети мигрантов, обучение детей мигрантов

Проблема адаптации детей мигрантов к русской языковой среде обсуждается в методологических исследованиях

\section{Железнякова}

\section{Елена Алексеевна,}

кандидат педагогических наук

дочент; доцент кафедры

межкультурной коммуникации Российского государственного педагогического университета им. А.И. Герцена (Санкт-Петербург),

elenazheleznyakova@yandex.ru

\section{Новикова}

Полина Васильевна,

аспирант, младший научный

сотрудник, Российский

государственный педаго-

гический университет

им. А.И. Гериена

(Санкт-Петербург),

polinovik@gmail.com уже более двадцати лет, однако и сегодня она сохраняет свою актуальность. Согласно данным Росстата на июнь 2019 г. [1], миграционный поток в Россию продолжает расти. Для решения этой проблемы были разработаны различные программы («Столичное образование», проект «Школы России» и др. ), целью которых была помощь в интеграции детей, для которых русский язык является неродным, в российское образовательное пространство.

Авторы, собрав актуальную информацию о ранее и ныне действующих организациях, работающих в сфере языковой адаптации детей-инофонов, проанализировав результаты, существующие пути языковой адаптации детей мигрантов и пришли к выводу, что наиболее эффективный и действенный путь - дополнительная корректировочная работа по русскому языку.

Методика преподавания русского языка как неродного вслед за методикой преподавания русского языка как иностранного предполагает взаимосвязанное обучение видам речевой деятельности на уроке. В данной статье мы остановимся на аудировании.

Аудирование - один из самых сложных видов речевой деятельности в обучении мигрантов русскому языку, «так как включает целый ряд операций: сличение, узнавание, идентификацию, смысловой синтез» [4, с. 173]. Кроме того, это один из важнейших видов речевой деятельности - слуховое восприятие и понимание необходимо для работы и повседневной жизни в стране. $\mathrm{C}$ него начинается овладение устной формой общения. «Аудирование включает в себя следуюшие аудитивные навыки, интеграчия которых обеспечивает владение этим видом речевой деятельности: 1) слухо-произносительные навыки; 2) реиептивные лексико-грамматические навыки» [7, с. 122].

Посредством аудирования достигаются определенные воспитательные, образовательные и развивающие цели: у обучающихся формируется умение предвосхищать содержание звучащей речи, развивается способность внимательного вслушивания, происходит тренировка и развитие кратковременной и долговременной памяти за счет необходимости удерживания информации, закладывается фундамент для других видов речевой деятельности.

Существует несколько классификаций сложностей, с которыми сталкивается слушающий. Назовем те, ко- 
торые наиболее сильно влияют на овладение аудированием детьми-инофонами:

- невозможность регулировать длительность речи;

- языковые сложности (незнакомый материал, устная форма воспроизведения знакомого материала);

- трудности, связанные с содержательной стороной высказываний;

- условия предъявления текста и источники [2, c. 120-123].

Аудирование может выступать как средство и как цель обучения. В нашем случае мы будем рассматривать его во второй роли, имея в виду цель научить ребенкаинофона понимать речь на слух с первого раза.

Обучение строится на основе прослушивания того или иного текста и работе с ним. Вид и цель аудирования определяют отбор текста и принцип обучения. Повтор прослушивания, длительность, сложность, источник детерминированы этапом обучения. Тексты должны быть актуальны для возрастной категории, обусловлены целями изучения (в нашем случае - учеба и проживание в России).

Особое место в обучении аудированию занимает предтекстовая работа, которая состоит из упражнений, направленных на снятие языковых трудностей.

В отечественной методике чаще всего выделяют тренировочные (подготовительные) и речевые (коммуникативные) упражнения. Существует разделение упражнений в соответствии с этапами: предтекстовые, текстовые и послетекстовые. Нас интересуют тренировочные (подготовительные) или, по другой классификации, предтекстовые упражнения. Они «вырабатывают восприятие, тренируют слуховую память, способность прогнозировать форму и содержание, кратковременную память на удержание информации» [4, с. 175].
Д.Д. Дмитриева отмечает, что предтекстовые упражнения следует выполнять непосредственно перед прослушиванием, так как они призваны усилить мотивацию и сформировать первичную установку «на прослушивание аудиотекста, а также на снятие основных трудностей, возможных при последующем его восприятии и понимании»; на этапе предтекстовых упражнений «активизируется словарный запас по определенной теме, происходит актуализация социокультурных знаний по теме прослушивания, снимаются языковые трудности и психологическое напряжение учащихся» [3, с. 214].

Для совершенствования навыков понимания живой естественной речи необходимо знакомить учащихся с аутентичными текстами, языковое и когнитивное содержание которых соответствует уровню владения русским языком обучаемых. Чтобы формирование навыков аудирования было эффективным, инофонов следует подготовить к восприятию текста. В этом помогут следующие приемы (примеры заданий взяты из учебных пособий по адаптации детей-мигрантов младшего и среднего школьного возраста $[5,6]$ :

1) активизация знаний о дискурсе путем сообщения того, какой именно текст будет прослушиваться:

- Послушай стихотворения о школьных принадлежностах. Повторлйте хором за учителем.

- Послушай диалог ученичы и библиотекаря и ответь на вопросы.

- Послушай, что нам рассказывает кошка, и ответь на вопросы.

2) предоставление необходимой фоновой информации о содержании текста:

- Посмотри на картинку. Это Лусинэ. Послушай рассказ о Лусинэ. Расскажи о себе.

- Посмотри на картинки. Это Саша. Что делает Саша? 
Повтори за учителем.

3) прослушивание текста в сокращенном, упрощенном или замедленном варианте записи:

- Смотри на картинку и повторяй за учителем.

- Повторлй за учителем.

Это красная шапка. Это зеленая куртка. Это черная юбка. Это красивая футболка.

4) беседа по рисункам, репродукциям, фотографиям и т.п., которые создают определенные ожидания о говорящих или событиях, изображенных в тексте:

- Смотри на картинки. Слушай и повторяй.

5) предоставление ключевых (опорных) слов и выражений: учащиеся могут использовать слова, для того чтобы выдвинуть предположения, о ком или о чем пойдет речь:

- Составъ предложения с этими словами. (Далее - слуховое восприятие текста с употреблением слов из данного упражнения).

- Послушай слова. Скажи, какое слово лишнее. (Далее - слуховое восприятие текста с употреблением слов из данного упражнения).

6) обсуждение темы текста:

- Как ты думаешъ, когда мъ говорим «приходи», а когда «приходите»? Когда мы говорим «давай пойдем», а когда «давайте пойдем»? (Далее - слуховое восприятие текста на тему, связанную с данным упражнением)

- Рассмотри табличу и обсуди с учителем (Монолог/Диалог - происхождение понятий, определение). Послушай, как учитель прочитает монолог и диалог. Устно, а затем выразительно вслух самостоятельно прочитай монологи. В парах прочитайте диалоги.

7) чтение аннотации (резюме):

- Сегодна мы поговорим о русских народных сказках. Русские народные сказки любят все: дети и взрослые. Русских народных сказок очень много, и все они разные: про животных, про вол шебные события, про растения, про фантастических существ.

В русской литературе очень много сказок про животных, про птии. Часто в сказках они могут разговаривать человеческим голосом, общатвся друг с другом и слюдьми.

Послушай русскую народную сказку «Курочка Ряба».

Опыт обучения детей-инофонов в рамках проекта «Школа мигранта. Добро пожаловать в Ленинградскую область» показал, что предтекстовая работа с использованием выделенных приемов снимает часть аудитивных трудностей и позволяет использовать аутентичные звучащие материалы уже на начальном этапе обучения русскому языку как неродному.

\section{Лumepamypa:}

1. Федеральная служба государственной статистики: Демография. URL: http://www. gks.ru/wps/wcm/connect/rosstat_main/rosstat/ru/statistics/population/ demography/\# (дата обращения 02.11.2019)

2. Балыхина T.M. Методика преподавания русского языка как неродного (нового): Учебное пособие для преподавателей и студентов. М.: Изд-во РУДН, 2007. С. 115125.

3. Дмитриева Д.Д. Особенности организации работы с новым лексическим материалом при обучении аудированию на занятиях по русскому языку как иностранному (предтекстовый этап) // Балтийский гуманитарный журнал. 2019. Т. 8. № 1 (26) C. 213-215.

4. Зайцева С.Е. Методика обучения аудированию // Инновационная наука. 2017. № 1. С. $172-175$.

5. Учебные материалы по социально-культурной адаптации детей мигрантов младшего школьного возраста / Под общей ред. И. П. Лысаковой. СПб, 2019.

6. Учебные материалы по социально-культурной адаптации детей мигрантов среднего школьного возраста / Под общей ред. И. П. Лысаковой. СПб, 2019.

7. Цой Е.В. Обучение аудированию на основном этапе. Методические рекомендации // Обучение русскому языку детей мигрантов. Статьи и методические материалы / Отв. редактор 0. В. Горских. Томск: Региональный центр развития образования, 2012 C. $121-126$. 


\section{Elena Zheleznyakova,}

PhD in Pedagogics, Associate Professor; Associate Professor of the Department

of intercultural communication, A.I. Herzen Russian State Pedagogical University

(Saint Petersburg), elenazheleznyakova@yandex.ru

\section{Polina Novikova,}

Post-graduate student, Junior researcher,

A.I. Herzen Russian State Pedagogical University (Saint Petersburg),

polinovik@gmail.com

\section{Listening in teaching Russian to migrant children:}

\section{pre-text work}

The article deals with the techniques facilitating the formation of listening skills at the stage of pre-text work. The experience of teaching children of migrants has shown that these techniques remove some of the listening difficulties and allow the use of authentic audio materials at the initial stage of teaching Russian as a non-native language.

The research was carried out with the financial support of the RFBR in the framework of the scientific project no.19-013-00213.

Keywords: Russian as a non-native language, speech activity, listening, pre-text work, children of migrants

\section{Болот Арзыматов}

\section{Феномен школы с этнокультурным компонентом в системе московского образования}

В статье рассматриваются проблемы образования детей из семей иноэтничных мигрантов. Анализируется опыт г. Москвы в сфере организации доступа детей из семей мигрантов к образованию в образовательных учреждениях. Описываются некоторые подходы к их обучению и созданию благоприятной интеграционной среды. Обосновывается необходимость разработки и реализации в российском образовательном пространстве единого концептуального подхода к социально-культурной, языковой и социально-психологической адаптации обучающихся из семей иноэтничных мигрантов. Доказывается, что образование этих детей - важный долгосрочный стратегический приоритет и инвестиция в будущее России и всего мира.

Ключевые слова: международная миграция, этнокультурный компонент, образование детей мигрантов, социальная адаптация мигрантов, полиэтническая школа, статистика детской миграции, кыргызская диаспора, манасоведение, разговорный клуб, кыргызы в Москве

Международная миграция характеризуется увеличением количества участвующих в ней стран и людей, скоростью миграционных потоков. В миграционные процессы вовлечены люди самых разных национальностей, которые го-

\section{Арзыматов}

Болот Мамбеттурдуевич

Иссык-Кульский государственный университет им. К. Тыныстанова, (Каракол, Кыргызская Республика), магистрант программы «Межэтнические и межконфессиональные отношения в образовании», Московский педагогический государственный университет (Москва) arzymatov_bolot@mail.ru ворят на различных языках, исповедуют разные религии, придерживаются разных обычаев. При этом вплоть до 1960-1970-х гг. большинство мононациональных стран, принимавших иммигрантов, справлялись с передачей им своих культурных образцов. Включаясь в новое общество, люди по большей части отказывались от культурных и политических традиций прежней родины, утрачивали приверженность ее 